
ISSN : 2615-1995, E-ISSN : 2615-0654

J. Madani., Vol. 3, No. 1, Maret 2020 (95 - 103)

C2018 Lembaga Kajian Demokrasi

dan Pemberdayaan Masyarakat (LKD-PM)

DOI : https://doi.org/10.33753/madani.v3i1.91

\title{
Pengaruh Modal Kerja dan Current Ratio (CR) Terhadap Return on Asset (ROA) Pada Perusahaan PT Indofood Tbk Pada Periode 2008-2017
}

\author{
Krisnaldy \\ Fakultas Ekonomi, Universitas Pamulang \\ krisnaldyunpam@gmail.com
}

\begin{abstract}
Abstrak
Tujuan penelitian ini adalah untuk mengetahui terdapat pengaruh modal kerja terhadap Return On Asset perusahaan (ROA) PT Indofood.Tbk yang terdaftar di BEI tahun 2008-2017, untuk mengetahui terdapat pengaruh Current Ratio (CR) terhadap Return On Asset perusahaan PT.Indofood.Tbk yang terdaftar di BEI tahun 2008-2017 dan untuk mengetahui Apakah terdapat pengaruh modal kerja dan Current Ratio (CR) secara simultan pada Return On Asset (ROA) perusahaan PT.Indofood.Tbk yang terdaftar di BEI 2008-2017 . Metode Penelitian yang dilakukan bersifat deskriptif kuantitatif. Deskriptif, Penelitian deskriptif merupakan metode penelitian yang digunakan untuk menemukan pegetahuan yang seluas-luasanya terhadap objek penelitian pada suatu masa tertentu. Penelitian ini dilakukan untuk mengetahui pengaruh Modal Kerja dan Current Ratio terhadap Return on Asset (ROA). Untuk mendapatkan data dan informasi yang penulis perlukan dalam dalam ini. Mengadakan penelitian yang meliputi mencari serta melakukan observasi serta menggumpulakan data laporan keuangan Selama 10 (Sepuluh) tahunDari penelitian diperoleh secara simultan diketahui signifikan sebesar 0.012, ini menunjukkan bahwa nilai signifikasi lebih kecil dari 0,05 atau 0,012<0,05, sehingga dapat disimpulkan jika nilai signifikasi sig<0,05 maka $\mathrm{H}_{0}$ di tolak dan $\mathrm{H}_{3}$ di terima sehingga Modal Kerja dan Current Ratio berpengaruh terhadap Return on Asset perusahaan
\end{abstract}

Kata Kunci : Return on Asset, Current Ratio, Modal Kerja

\begin{abstract}
The purpose of this research is to find out the influence of Working Capital on the Return on Assets of PT Indofood.Tbk companies listed on the Indonesia Stock Exchange in 2008-2017. Tbk registered on the Indonesia Stock Exchange in 2008-2017 and to find out whether there is an influence of working capital and Current Ratio (CR) simultaneously on the Return on Assets (ROA) of PT Indofood.Tbk company registered on the Indonesia Stock Exchange 2008-2017. The research methodology is quantitative descriptive. Descriptive, descriptive research is a research method used to find the broadest possible knowledge of the object of research at a particular time. This research was conducted to determine the effect of Working Capital and Current Ratio on Return on Assets (ROA). To get the data and information that the writer needs in this thesis. Conducting research which includes searching and observing and collecting financial statement data for 10 (ten) years. From the research obtained simultaneously it is known to be significant at 0.012, this shows that the significance value is less than 0.05 or $0.012<0.05$, so it can be concluded if significance value sig $<0.05$ then $\mathrm{H}_{0}$ is rejected and $\mathrm{H}_{3}$ is accepted so that Working Capital and Current Ratio affect the company's Return On Assets
\end{abstract}

Keywords : Return on Asset, Current Ratio, Capital Work 


\section{PENDAHULUAN}

Dalam persaingan dunia usaha yang semakin mengglobal dan perkembangan teknologi yang semakin berkembang. Perusahan dituntut untuk dapat bersaing dan memepertahankan posisinya, dan bahkan perusahaan diharuskan untuk mampu menguasai persaingan. Perusahaan yang memiliki kemampuan beradaptasi dengan situasi dan kondisi yang terus berubah, bahkan dengan krisis global yang menerpa dunia usaha, adalah perusahaan yang memiliki pertahanan diri yang kuat, artinya sukses atau tidaknya perusahaan dalam perkembangannya sangat bergantung pada faktor internal dan eksternal, khususnya pada faktor internal perusahaan yang berhubungan dengan kinerja keuangannya.

Bagi pihak manajeman, keuntungan yang diperoleh merupakan pencapaian rencana (target) yang telah ditentukan sebelumnya. Pencapaian target keuntungan sangat penting karena dengan mencapai target yang telah ditetapkan atau bahkan melebihi target yang diinginkan, hal ini merupakan prestasi tersendiri bagi pihak manajemen. Prestasi ini merupakan ukuran untuk menilai kesuksesan manajemen dalam mengelola perusahaan (baik jenjang karier maupun penghasilan) demikian pula sebaliknya apabila manajemen gagal mencapai target, hal ini merupakan cermin kegagalan manajemen dalam mengelola perusahaan. kegagalan mencapai target dapat merusak citra dan kepercayaan dari pemilik kepada karier manajemen ke depan (Kasmir, 2017: 2).

Agar tercapainya target yang diinginkan perusahaan dibutuhkan laporan keuangan, laporan keuangan merupakan sumber informasi keuangan yang utama disusun oleh perusahaan berdasarkan pada prinsip-prinsip akutansi. Kasmir (2010: 7) menjelaskan lebih lanjut bahwa dalam praktiknya dikenal beberapa macam laporan keuangan seperti laporan keuangan neraca, laba rugi, arus kas, perubahan modal dan catatan atas laporan keuangan. Semua laporan tersebut secara garis besar menggambarkan kondisi perusahaan yang memudahkan berbagai pihak yang berkepentingan dalam kinerja keuangan. Penilaian pada kinerja perusahaan dapat di- laksanakan dengan menganalisis laporan keuangan perusahaan.

Sulistyani(2018:76) menyatakan profitabilitas merupakan suatu kemampuan perusahaan untuk mewujudkan suatu keuntungan bagi perusahaan atau merupakan suatu pengukuran akan efektivitas pengelolaan perusahaan dalam mengelola manajemennya. Secara umum ada tiga jenis rasio profitabilitas yang dominan dipakai dalam penelitian yaitu profit margin, return on asset (ROA), dan return on equity (ROE), ROA merupakan salah satu indikator yang terbaik untuk mengukur kinerja perusahaan dimana ROA bisa ditentukan oleh serangkaian kebijakan perusahaan dan dipengaruhi oleh faktor-faktor lingkungan. Tingkat profitabilitas yang tinggi menunjukkan kinerja manejerial yang baik.

\section{Pembatasan Masalah}

Berdasarkan identifikasi masalah di atas yang cukup luas agar tujuan penelitian dapat tercapai, maka penulisan membatasi masalah penelitian yaitu: modal kerja adalah modal kerja adalah modal yang digunakan untuk membiayai oprasional perusahaan sehari-hari, terutama yang memilki jangka pendek (Kasmir 2010:210). Current Ratio merupakan merupakan rasio untuk mengukur kemampuan perusahaan dalam membayar kewajiban jangka pendeknya atau utang yang segera jatuh tempo pada saat ditagih secara keseluruhan (Kasmir, 2017:134) Return on Asset merupakan rasio yang menunjukkan hasil (return) atas jumlah aktiva yang digunakan dalam perusahaan (Kasmir, 2017: 202). Data yang digunakan dalam penelitian ini yaitu laporan keuangan yang diterbitkan oleh perusahaan PT Indofood Indonesia. Tbk. Data yang diteliti adalah laporan keungan tahun 2008-2017.

\section{METODE}

\section{Tempat dan Waktu Penelitian}

Penelitian ini dilakukan untuk mengetahui pengaruh Modal Kerja dan Current Ratio terhadap Return on Asset (ROA). Untuk mendapatkan data dan informasi yang penulis perlukan dalam dalam ini. Mengadakan penelitian yang 
meliputi mencari serta melakukan observasi serta menggumpulakan data laporan keuangan Selama 10 (Sepuluh) tahun dan informasi yang berhubungan dengan PT Indofood, Tbk. yang beralamat Jl Jendral Sudirman No 27 Jakarta, 12810 Indonesia. Tel (62-21)-5795822. Fax (6221)-579535960 Alamat website www.Indofood. com. Waktu penelitian diamblil selama 3 (tiga) bulan terhitung mulai bulan maret sampai dengan bulan juni 2018 dan data yang diambil oleh penulis berupa laporan keuangan PT Indofood Indonesia, Tbk. Periode 2008 sampai dengan 2017.

\section{Sifat Penelitian}

Penelitian yang dilakukan penulis dalam menyusun ini bersifat deskriptif kuantitatif. Deskriptif menurut Hidayat (2010: 34) penelitian deskriptif merupakan metode penelitian yang digunakan untuk menemukan pegetahuan yang seluas-luasanya terhadap objek penelitian pada suatu masa tertentu. Sedangkan menurut Punaji (2010: 89) penelitian deskriptif adalah penelitian yang tujuannya untuk menjelaskan atau mendekan suatu peristiwa, keadaan, objek apakah orang, atau segala sesuatu yang terkait dengan variabel-variebel yang bisa dijelaskan baik menggunakan angka-angka maupun kata-kata.

\section{Populasi dan Sampel}

Populasi menurut Sugiyono (2010: 80) adalah wilayah generalisasi yang terdiri atas: objek/ subjek yang mempunyai kualitas dan karakteristik tertentu yang ditetapkan oleh peneliti untuk dipelajari dan dikemudian ditarik kesimpulannya. Populasi yang digunakan dalam ini adalah laporan keuangan PT Indofood, Tbk. Menurut Sugiyono (2010: 81) Sampel adalah bagian dari jumlah dan karakteristik yang dimiliki oleh populasi tersebut. Bila populasi besar dan peneliti tidak mungkin mempelajari semua yang ada pada populasi, misalnya karena keterbatasan dana, tenaga, dan waktu, maka peneliti dapat menggunakan sampel yang diambil dari populasi itu. Sampel yang digunakan dalam ini yaitu berupa laporan keuangan pada PT Indofood Tbk, priode 2008 sampai dengan 2017.

\section{Sumber Data Penelitian}

Data-data yang digunakan dalam penelitian ini diperoleh dari data sekunder yang bersifat kuantitatif. Data sekunder merupakan data yang informasinya diperoleh secara tidak langsung dari perusahaan. Data-data sekunder tersebut berupa rasio-rasio laporan keuangan dari laporan keuangan PT. Indofood, Tbk. Pada penelitian ini data sekunder tersebut didapat dengan cara sebagai berikut:

- Riset Kepustakaan (Library Research). Penelitian ini bertujuan untuk memperoleh data dan informasi yang bersifat teoritis melalui riset kepustakaan dengan mencari literatur-literatur dan buku-buku ilmiah yang berkaitan dengan masalah yang dibahas dalam penelitian sehingga dapat dijadikan landasan dalam menganalisa permasalahan dalam penulisan.

- Studi Lapangan (Field Research). Penelitian ini dilakukan dengan cara menggumpulkan data perusahaan yang berupa data laporan keuangan tahunan PT Indofood, Tbk.

\section{HASIL dan PEMBAHASAN \\ Laporan Keuangan}

Manajemen rasio keuangan (financial ratio management) adalah alat manajemen yang digunakan untuk menganalisis laporan keuangan dengan cara menghitung rasio-rasio keuangan yang akan digunakan dalam penentuan kebijakan. Rasio tersebut mengacu pada standar ukuran yang sederhana. Rasio dapat menstandari saingan si informasi keuagan yang dapat dipakai sebagai alat pembandingan antar perusahaan dengan ukuran yang berbeda. (Siagian, 2010: 155)

Sebagai fase terakhir dari siklus atau proses akutansilaporan keuangan memberikan informasi penting tentang keadaan suatu perusahaan yang dapat ditafsirkan secara kuantitatif dan kualitatif. (Siagian, 2010: 155). Kuantitatif berarti memuat angka-angka dalam satuan mata uang, sedangkan kualitatif menggambarkan keadaan dan perkembangan fisik dan kegiatan perusahaan dalam oprasionalnya memproduksi dan menjual produk yang dihasilkan, memperoleh 
laba dan sebagainya. (siagian, 2010:155). Dengan demikian, laporan keuangan (financial statement) dapat didefinisikan sebagai "suatu informasi kuantitatif dan kualitatif tentang keadaan keuangan perusahaan pada suatu priode pembukuan tertentu “. (Siagian, 2010: 156).

Dalam pengertian yang sederhana, laporan keuangan adalah laporan yang menunjukkan kondisi keuangan perusahaan pada saat ini atau dalam suatu priode tertentu. (Kasmir, 2017: 7). Berdasarkan penjelasan di atas dapat disimplkan bahwa laporan keuangan adalah informasi yang menggambarkan keadaan perusahaan pada periode tertentu dalam jenis kuantitatif, yang berguna untuk mengambil keputusan ekonomi yang sifatnya fiansial.

\section{Tujuan Laporan Keuangan}

Laporan keuangan diketahui memiliki tujuan tertentu. Dalam praktiknya terdapat beberapa tujuan yang hendak dicapai, terutama bagi pemilik usaha dan manjeman perusahaan. Secara umum laporan keuangan bertujuan untuk memberikan informasi keungan suatu perusahaan, baik pada saat tertentu maupun pada priode tertentu. Laporan keuangan juga dapat disusun secara mendadak sesuai kebutuhan perusahaan maupun secara berkala. Jelasnya adalah laporan keuangan mampu memberikan informasi keuangan kepada pihak dalam dan luar perusahaan yang memiliki kepentingan terhadap perusahaan. (Kasmir, 2017: 10) Berikut ini beberapa tujuan pembuatan atau penyusunan laporan keuangan yaituS: (Kasmir, 2017: 11) Memberikan informasi tentang jenis dan jumlah aktiva (harta) yang dimiliki perusahaan pada saat ini. Memberikan informasi tentang jenis dan jumlah kewajiban dan modal yang dimiliki perusahaan pada saat ini. Memberikan informasi tentang jenis dan jumlah pendapatan yang diperoleh pada suatu periode tertentu. Memberikan informasi tentang jumlah biaya dan jenis biaya yang dikeluarkan perusahan dalam suatu periode tertentu. Memberikan informasi tentang perubahan-perubahan yang terjadi terhadap aktiva, pasiva, dan modal perusahaan. Memberikan informasi tentang kinerja manajeman perusahan dalam suatu periode. Memberikan informasi tentang catatan-catatan atas laporan keuangan Informasi keuangan lainnya. Berdasarkan uraian di atas dapat disimpulkan bahwa bahwa tujuan laporan keuangan adalah dengan memperoleh laporan keuangan perusahaan dapat mengetahui posisi kondisi keuangan perusahaan secara menyeluruh, untuk mengetahui kondisi keuangan perusahaan, laporan keuangan bukan hanya dibaca saja, tetapi dimengerti dengan cara dianalisis keuangannya melaluai berbagai rasio keuangan yang lazin digunakan.

\section{Jenis-Jenis Laporan Keuangan}

\section{1) Neraca}

Neraca merupakan ringkasan laporan keuangan. Artinya, laporan keuangan disusun secara garis besarnya saja dan tidak mendetail. Kemudian, neraca juga menunjukkan posisi keuangan berupa aktiva (harta), kewajiban (utang), dan modal peusahaan (ekuitas) pada saat tertentu. Artinya neraca dapat dibuat untuk mengetahui kondisi (jumlah dan jenis) harta, utang, dan modal perusahaan. Maksud pada tanggal tertentu setiap saat dibutuhkan, namun neraca dibuat biasanya akhir tahun atau kuartal. Menurut James C Van Horne dalam buku Kasmir, (2017: 30) neraca adalah ringkasan posisi keuangan perusahaan pada tanggal tertentu yang menunjukkan total aktiva dengan total kewajiban ditambah total ekuitas pemilik.

\section{2) Laporan Laba Rugi}

Jenis laporan keuangan lainnya selain neraca adalah laporan keuangan laba rugi. Berbeda dengan neraca yang melaporkan informasi tentang kekayaan, utang, dan modal, laporan laba rugi memberikan informasi tentang hasil-hasil usaha yang diperoleh perusahaan. Laba rugi juga berisi jumlah pendapatan yang diperoleh dan jumalah biaya yang dikeluarkan. Dengan kata lain, laporan laba rugi merupakan laporan yang menunjukkan jumlah pendapatan atau penghasilan yang diperoleh dan biaya-biaya yang dikeluarkan dan laba rugi dalam suatu periode tertentu. Menurut James C. Van Horne, dalam buku 
Kasmir (2017: 45) yaitu ringkasan pendataan dan biaya perusahaan selama periode tertentu diakhiri dengan laba atau rugi pada periode tersebut. Laporan laba rugi terdiri dari penghasilan dan biaya perusahaan pada periode tertentu, biasanya untuk satu tahun atau tiap semester enam bulan atau tiga bulan.

\section{3) Laporan Perubahan Modal}

Menurut Kasmir (2017: 29) laporan perubahan modal merupakan laporan yang berisi jumlah dan jenis modal yang dimiliki saat ini, kemudian laporan ini juga menjelaskan perubahan modal dan sebab-sebab terjadinya perubahan modal di perusahaan. Laporan perubahan modal jarang dibuat bila tidak terjadi perubahan modal. Artinya laporan ini baru dibuat bila memang ada perubahan modal. Sedangkan menurut Siagian (2010: 159) Laporan perubahan modal atau laba ditahan yaitu laporan yang menunjukkan perubahan besar modal sebagai akibat adanya perolehan laba atau rugi pada suatu periode tertentu.

\section{4) Laporan Arus Kas}

Menurut Kasmir (2017: 29) Laporan arus kas merupkan laporan yang menunjukkan semua aspek yang berkaitan dengan kegiatan perusahaan, baik yang berpengaruh langsung atau tidak langsung terhadap kas. Laporan arus kas harus disusun berdasarkan konsep kas selama periode laporan. Laporan kas terdiri arus kas masuk (cash in) dan arus kas keluar (cash out) selama periode tertentu. Kas masuk terdiri uang yang masuk perusahaan, seperti hasil penjualan atau penerimaan lainnya, sedangkan kas keluar merupakan sejumlah jumlah pengeluaran dengan jenisjenis pengeluarannya, seperti pembayaran biaya operasional perusahaan

\section{Pihak-Pihak yang Berkepentingan Terhadap Laporan Keuangan}

Menurut Kasmir (2017: 25) Pihak-pihak yang berkepentingan terhadap suatu laporan keuangan adalah:

1. Pemilik, guna melihat perkembangan dan kemajuan prusahaan serta dividen yang diperolehnya.

2. Manjeman, untuk menilai kinerjanya selama periode tertentu.

3. Kreditor, untuk menilai kelayakan perusahaan dalam memperoleh pinjaman dan kemampuan membayar pinjaman.

4. Pemerintah, untuk menilai kepatuhan perusahaan untuk membayar kewajiban kepeda pemerintah.

Investor, untuk menilai prospek usaha tersebut ke depan, apakah mampu memberikan dividen dan nilai saham seperti yang diinginkan.

\section{Modal Kerja}

Dalam praktiknya dana yang memilki oleh perusahaan, baik dana pinjaman maupun modal sendiri, dapat digunakan untuk dua hal, pertama digunakan untuk keperluan investasi, artinya dana ini digunakan untuk membeli atau membiayai aktiva tetap dan bersifat jangka panjang yang dapat digunakan secara berulangulang, seperti pembelian tanah, bangunan, mesin, kendaraan dan aktiva tetap lainnya. Kedua, dana digunakan untuk membiayai modal kerja, yaitu modal kerja yang digunakan untuk pembiayaan jangka pendek, seperti pemebelian bahan baku, membayar gaji dan upah, dan biaya-biaya operasional lainnya (Kasmir, 2017: 248), Ada beberapa pengertian modal kerja menurut para ahli diantaranya:

Menurut Kasmir (2017: 250) pengertian modal kerja merupakan modal yang digunakan untuk melakukan kegiatan operasi perusahaan. Modal kerja dapat diartikan sebagai investasi yang ditanamkan dalam aktiva lancar atau aktiva jangka pendek, seperti kas, bank, surat-surat berharga, piutang, persediaan, dan aktiva lancar lainnya. Menurut Fahmi (2016: 41) pengertian modal kerja merupakan salah satu unsur aktiva yang sangat penting dalam perusahaan. karena tanpa modal kerja perusahaan tidak dapat memenuhi kebutuhan dana. Untuk menjalankan aktivitasnya.

Menurut Sutrisno (2013: 100) modal kerja adalah investasi sebuah perusahaan pada aktivaaktiva jangka pendek-kas, sekuritas, persediaan 
dan piutang. Berdasarkan uraian di atas dapat disimpulkan bahwa modal kerja merupkan dana yang merupakan investasi perusahaan yang digunakan untuk kegiatan oprasional kerja terutama biaya yang memilki jangka pendek, bertujuan untuk mempertahankan kelangsungan kegiatan perusahaan.

\section{Fungsi Modal kerja}

Fungsi modal kerja memiliki Beberapa fungsi diantaranya:

a) Modal kerja itu menampung adanya akibat buruk yang akan timbul karena menurunnya aktiva lancar, contohnya menurunya piutang yang diragukn dan yang tidak dapat ditagih dan menurunya tingkat persediaan.

b) Modal kerja yang memungkinkan suatu perusahaan untuk membayar semua utang lancarnya tepat pada waktunya dan untuk memanfaatkan potongan tunai, dengan menggunakan potongan tunai maka jumah yang akan dibayarkan untuk pembelian barang menjadi berkurang.

c) Modal kerja yang cukup memungkinkan perusahaan untuk memelihara Credit Standing perusahaan adalah penilaian terhadap pihak ketiga, seperti bank dan para kreditur akan kelayakan perusahaan untuk memelihara kredit. Di samping itu modal kerja yang mencukupi memungkinkan perusahaan untuk menghadapi situasi darurat seperti dalam hal terjadi: pemogokan banjir dan kebakaran.

d) Adanya kemungkinan perusahaan untuk memberikan syarat kredit kepada para pembeli. Kadang-kadang perusahaan harus memberikan kepada para pembelinya syarat kredit yang lebih lunak dalam usaha membantu para pembeli yang baik untuk membiayai operasinya.

e) Memungkinkan perusahaan untuk menyesuaikan persediaan pada suatu jumlah yang mencukupi untuk melayani kebutuhan para pelanggan secara lancar.

\section{Faktor yang Berpengaruh Terhadap Modal Kerja}

Menurut Kasmir (2010: 254) menyatakan bahwa: "kebutuhan perusahaan akan modal tergantung pada faktor-faktor sebagai berikut: Macam-macam perusaahaan modal kerja tergantung pada jenis dan sifat dari usaha yang dijalankan perusahaan. Waktu produksi Ada keterkaitan langsung antara jumlah modal kerja dan jangka waktu yang diperlukan untuk memproduksi barang yang akan dijual kepada pembeli. Makin lama waktu yang diperlukan untuk memperoleh barang, atau makin lama waktu yang diperlukan untuk memperoleh barang dari luar negeri, jumlah modal kerja yang diperlukan makin besar. Syarat kredit Kebutuhan modal kerja perusahaan dipengaruhi oleh syarat pembelian dan penjulan. Makin banyak diperoleh syarat kredit untuk membeli bahan dari pemasok maka lebih sedikit modal kerja yang ditanamkan dalam persediaan. Sebaliknya, semakin longgar syarat kredit yang diberikan pada pembeli maka akan lebih banyak modal kerja yang ditanamkan dalam piutang.

Tingkat perputaran persediaan semakin cepat persediaan berputar maka semakin kecil modal kerja yang diperlukan. Pengendalian persediaan yang efektif diperlukan untuk memelihara jumlah, jenis, serta kualitas barang yang sesuai dan mengatur investasi dalam persediaan. Di samping itu biaya yang berhubungan dengan persediaan juga berkurang.

\section{Hasil}

\section{Uji Normalitas}

Uji normalitas digunkan untuk menguji variabel bebas dan variabel terkait pada persamaan regresi yang di hasilkan, apakah berdistribusi normal atau berdistribusi tidak normal. Hasil pengujian normalitas data pada variabel Modal kerja, Current Ratio terhadap Return on Asset diperoleh hasil sebagai berikut:

Berdasarkan data histogram di bawah dapat dilihat bahwa tersebut hamper mendekati standar distribusi normal. Hal ini dapat dilihat dari nilai-nilai residual yang berdistribusi normal. Karena uji normalitas bukan dilakukan pada masing-masing variabel. Karena uji normalitas bukan dilakukan pada masing-masing variabel tetapi pada nilai risidualnya. Analisis lebih lanjut 
dengan menggunakan Normal Probability Plot of Regression Standardized Residua.

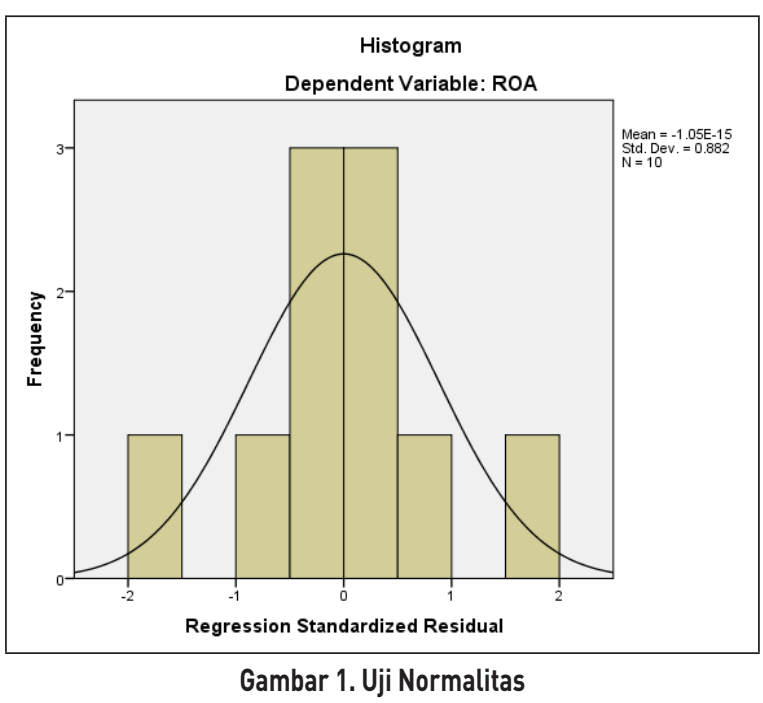

\section{Uji Koefisien Determinasi (Analisis Regresi)}

Untuk membuktikan dari hipotesis yang diajukan, maka peneliti ini menggunakan alat analisis regresi berganda yaitu berupa terdapat dua variabel independen (bebas) yang akan menjelaskan variabel dependen (terikat) dengan peelitian ini.

\begin{tabular}{|c|c|c|c|c|c|}
\hline \multicolumn{6}{|c|}{ Tabel 1. Koefisien Determinasi } \\
\hline \multicolumn{6}{|c|}{ Model Summary } \\
\hline Model & $\mathbf{R}$ & R Square & $\begin{array}{l}\text { Adjusted } \\
\text { R Square }\end{array}$ & $\begin{array}{l}\text { Std. Error } \\
\text { of the } \\
\text { Estimate }\end{array}$ & $\begin{array}{l}\text { Durbin- } \\
\text { Watson }\end{array}$ \\
\hline 1 & $847^{\mathrm{a}}$ & .717 & .636 & 03754 & 1,938 \\
\hline \multicolumn{6}{|c|}{ Sumber: hasil olahan spss } \\
\hline
\end{tabular}

Berdasarkan tabel di atas, maka diketahui nilai koefisien determinasi variabel Modal kerja dan Current Ratio terhadap Return on Asset sebesar 0,717 artinya bahwa kedua variabel independen (Modal kerja dan current ratio) mempunyai kontribusi yang kuat terhadap variabel dependen Return on Asset sebesar 71,7\% sedangkan sisanya sebesar 28,3\% dipengaruhi oleh variabel di luar penelitian. Dengan kata lain Modal Kerja dan Current Ratio bukan satu-satunya faktor yang mampu mempengaruhi Return on Asset, namun terdapat variabel lain yang juga memilki kontribusi dalam meningkatkan Return on Asset. Dengan demikian diperoleh model penelitian persamaan Regresi Berganda sebagai berikut: $Y=-0,191+-5,536 X_{1}+0,289 X_{2}$

Atau

$Y=-0,194+-5,536$ Modal Kerja + 0,289 Current Ratio

Dari persamaan di atas maka dapat diinterprestasikan beberapa hal, antara lain:

a. Nilai konstanta persamaan adalah 0,191 ini berarti jika variabel independen yaitu modal kerja $\mathrm{X}_{1}$ dan Current ratio $\mathrm{X}_{2}$ nilainya nol dan variabel dependen Return on Asset sebesar 0,194

b. Koefisiensi regresi variabel $\mathrm{X}_{1}$ modal kerja -5,536 artinya Modal Kerja terhadap Return on Asset memilki pengaruh negatif atau berlawanan arah terhadap Return on Asset, dimana untuk menaikan nilai Return on Asset maka nilai modal kerja harus di turunkan.

c. Koefisiensi regresi variabel $\mathrm{X}_{2}$ modal kerja 0,287 artinya Current Ratio terhadap Return on Asset memilki pengaruh positif atau searah terhadap Return on Asset, dimana untuk menaikan nilai Return on Asset maka nilai Current Ratio harus dinaikan.

\section{Pembahasan}

\section{Pengaruh Modal Kerja}

\section{Terhadap Return on Asset}

Dari penelitian diperoleh secara persial diketahui signifikan variabel $\mathrm{X}_{1}$ sebesar 0.004 , ini menunjukkan baha nilai signifikasi lebih kecil dari 0,05 atau $0,004<0,05$, sehingga dapat disimpulkan jika nilai signifikasi sig $<0,05$ maka $\mathrm{H}_{0}$ di tolak dan $\mathrm{H}_{1}$ di terima sehingga variabel modal kerja berpengaruh terhadap Return on Asset perusahaan. dikrenakan mengalami pasang surut dari tahun 2008 sampai 2015 karena modal kerja kuantitatif yang tidak stabil, namun pada tahun 2008 sampai tahun 2014 mngalami kenaikan yang bertahap dan kembali mengalami kenaikan kembali di tahun 2017. Meningkatnya akiva lancar dan meurunnya aktiva lancar. Dengan demikian untuk memperoleh modal kerja terhadap asset perlu diperhatikan modal kerja kuantitatif. 


\section{Pengaruh Current Ratio}

Terhadap Return on asset

Dari penelitian diperoleh secara persial diketahui signifikan variabel $\mathrm{X}_{2}$ sebesar 0.021 , ini menunjukkan bahawa nilai signifikasi lebih kecil dari 0,05 atau 0,021<0,05, sehingga dapat disimpulkan jika nilai signifikasi sig $<0,05$ maka $\mathrm{H}_{0}$ di tolak dan $\mathrm{H}_{2}$ di terima sehingga variabel Current Ratio berpengaruh terhadap Return on Asset perusahaan. rata-rata hasil Current Ratio $166,6 \%$ hal ini mengidentifikasi adanya kelebihan pada jumlah aktiva lancar, hal ini sebabkan oleh penambahan hutang lancar yang menyebabkan naiknya nilai kewajiban lancar sehingga dapat menyebabkan turunnya Retun On Asset. Saat mencapai likuiditas yang tinggi perusahaan selalu fokus pada kewajiban melunasi hutang dan mengabaikan investasi yang seharusnya menambah keuntungan. Dengan demikian perlu diperhatikan Current Ratio kuantitatifnya.

\section{Pengaruh Modal Kerja}

dan Current Ratio Terhadap Return on Asset

Dari penelitian diperoleh secara simultan diketahui signifikan sebesar 0.012 , ini menunjukkan bahwa nilai signifikasi lebih kecil dari 0,05 atau $0,012<0,05$, sehingga dapat disimpulkan jika nilai signifikasi sig $<0,05$ maka $\mathrm{H}_{0}$ di tolak dan $\mathrm{H}_{3}$ di terima sehingga Modal Kerja dan Current Ratio berpengaruh terhadap Return On Asset perusahaan. Selain itu di peroleh $\mathrm{F}_{\text {hitung }}$ 7,962 dan $\mathrm{F}_{\text {tabel }}$ 4,74 Sehingga dapat diketahui bahwa $\mathrm{F}_{\text {hitung }}$ $(7,962)>\mathrm{F}_{\text {tabel }}(4,74)$ jadi hipotesis nol ditolak, sehingga kesimpulannya yaitu varaibel Modal Kerja dan Current Ratio berpengaruh terhadap Return On Asset.

\section{SIMPULAN}

Berdasarkan hasil analisis penelitian dan pembahasan Modal Kerja dan Current Ratio, terhadap Return on Asset PT Indofood Tbk, maka dapat disimpulkan sebagai berikut: Secara parsial Modal Kerja berpengaruh signifikan terhadap Return on Asset, dengan nilai signifikansi sebesar 0,004 . Karena lebih kecil dari 0,05 jadi 0,004<0,05 sehingga $\mathrm{H}_{0}$ (nol) ditolak dan $\mathrm{H}_{1}$ diterima yang artinya Modal kerja berpengaruh positif terhadap Return on Asset. Secara persial Current Ratio berpengaruh signifikan terhadap Return on Asset, dengan nilai signifikansi sebesar 0,021. Karena lebih kecil dari 0,05 jadi $0,021<0,05$ sehingga $\mathrm{H}_{0}$ (nol) ditolak dan $\mathrm{H}_{2}$ diterima yang artinya Current Ratio berpengaruh positif terhadap Return on Asset. Secara simultan Modal Kerja dan Current Ratio berpengaruh positif sangat signifikan terhadap Return on Asset, dengan nilai signifikansi sebesar 0,016. Karena lebih kecil dari 0,05 jadi $0,012<0,05$ sehingga $\mathrm{H}_{0}$ (nol) ditolak dan $\mathrm{H}_{3}$ diterima yang artinya Modal Kerja dan Current Ratioberpengaruh positifterhadap ReturnonAsset. PT Indofood Tbk hendaknya lebih meningkatkan modal sendiri karena ini dimaksudkan untuk mengurangi biaya yang harus ditanggung oleh perusahaan dan juga untuk menjamin kontinuitas dari modal kerja, agar tidak terjadi kelebihan Modal kerja. Begitu pula sebaliknya perusahaan harus mengurangi penggunaan modal pinjaman agar dapat meningkatkan laba yang diperoleh perusahaan. PT Indofood Tbk memperhatikan kinerja keuangannya dengan serius dan sungguhsungguh, terutama pada modal kerja dan current ratio yang menjadi unsur penting dan berpengaruh terhadap pengelolaan masalah profitabilitas perusahaan.

\section{PENGHARGAAN}

Pada kesempatan kali ini penulis ingin mengucapkan terimakasih kepada semua yang terlibat baik secara langsung maupun tidak langsung yang tidak bisa penulis sebutkan satu persatu. Terimakasih atas saran, masukan, dan bantuan, semoga penelitian ini bisa bermanfaat bagi semua pihak.

\section{DAFTAR PUSTAKA}

Ambarwati, S D A. (2012). Manajemen keuangan. Edisi pertama cetakan pertama. Yogyakarta: Graha Ilmu

Fahmi, I, (2011). Analisis Laporan Keuangan Edisi Satu. Bandung: Alfabeta.

Fahmi, I. (2012). Analisis Laporan Keuangan Cetakan Kedua. Bandung: Alfabeta. 
Fahmi, I. (2013). Pengantar Manajemen Keuangan. Bandung: Alfabeta.

Ghozali, I. (2011). Aplikasi Analisis Multivariate dengan Program SPSS. Semarang: Universitas. Diponegoro.

Handoko, T. Hani. (2001). Manajemen Personalia dan Sumber Daya Manusia. Yogyakarta: BPFE.

Harahap, S S. (2011). Teori Akuntansi Edisi Revisi. Jakarta: Rajawali Pers.

Harahap, S S. (2015). Analisis Kritis Atas Laporan Keuangan Edisi Satu sampai Sepuluh. Jakarta: Rajawali Pers.

Ikatan Akuntansi Indonesia. (1995). Standar akuntasi keuangan. Jakarta: Salemba Empat.

Kasiram. (2008). Metodologi Penelitian Kuantitatif dan Kualitatif. Malang: UIN Malik Press.

Kasmir. (2010). Pengantar Manajemen Keuangan. Jakarta: Kencana Prenada Media Group.

Kasmir. (2017). Analisis Laporan Keuangan. Jakarta: Rajawali Pers.

Kasmir. (2017). Dasar-Dasar Perbankan Edisi Revisi 2008. Jakarta: PT. Raja Grafindo
Persada.

Kuswadi, (2009). Meningkatkan Laba Melalui Pendekatan Akuntansi Keuangan \& Akuntansi Biaya. Jakaarta: PT. Elex Media Komputindo. Munawir, S. (2010). Analisis Laporan Keuangan Edisi Keempat. Cetak Kelima Belas. Yogyakarta: Liberty.

Raharjo, B. (2009). Laporan Keuangan Perusahaan. Yogyakarta: Gajah mada University.

Siagian. (2010). Manajemen Keuangan Teori Dan Aplikasi. Edisi Empat. BPFE: Yogyakarta.

Sugiyono. (2011). Metode Penelitian Kombinasi. Bandung: Alfabeta.

Sugiyono. (2012). Metode Penelitian Kuantitatif Kualitatif dan R\&D. Bandung: Alfabeta

Sugiyono. (2015). Metode Penelitian. Bandung: Alfabeta.

Sulistiyani. (2018). Pengaruh Modal Kerja Terhadap Return on Asset (ROA) Pada Perusahaan PT. Fast food. Tbk pada periode 2009 - 2017. Jurnal Semarak Vol. 1, No. 3.

Sutrisno, (2013). Manajemen Keuangan Konsep \& Aplikasi, Edisi Pertama cetakan. 